\title{
Extinction-risk coverage is worth inaccuracies
}

\section{The media raised awareness of an important issue, even if they got some details wrong.}

Sir-Millions of people worldwide learned that climate change poses serious extinction risks to species as a direct result of the news coverage surrounding the Letter to Nature by Chris D. Thomas et al. (Nature 427, 145-148; 2004). Should Nature have blocked publicity on this story to prevent possible reporting inaccuracies, as Richard J. Ladle and colleagues (Nature 428, 799; 2004) suggest? We don't believe so.

Ladle and his colleagues correctly point out that the time-frame of extinctions was widely misreported. We knew this aspect of the story would be technically difficult, so our press releases in both the United Kingdom and the United States emphasized the correct interpretation in stand-alone paragraphs and italicized key words. The Letter to Nature itself emphasized this point, and we stressed the correct time-frame interpretation to every reporter who contacted us. The majority of reporters to whom we spoke in the United States got the time-frame issue right, although several still misreported it, or fell victim to headlinewriters at their news organizations who exaggerated the findings.

Still, the critical issue of connecting species extinctions to climate change was thrust before a broad American public. The story was covered by the most-watched news programme in the United States, the most-listened to radio network, one of the three major news magazines, and five of the top ten newspapers. More than 13 million people saw news programmes on the subject, and total readership of the newspapers covering the story was greater than 21 million. Including radio and magazines, we conservatively estimate that more than 40 million Americans read, heard or saw a story on this topic. The raised profile of the issue led to testimony being given before the US Senate by one of the study's co-authors.

Breaking through a US media climate often dominated by news of war, terror or the latest celebrity escapades is a victory. We have every obligation to help reporters understand and fact-check their stories before publication, and will continue to commit resources to that effort. But although the reporting wasn't perfect, we believe the benefits of the wide release greatly outweighed the negative effects of errors in reporting.

Lee Hannah, Brad Phillips

Center for Applied Biodiversity Science, Conservation International, 1919 M Street NW, Washington, DC 20036, USA

\section{Saving vital time in the war on drug resistance}

Sir - Your News story "Defence work sheds light on hospital bacteria" (Nature 428, 457; 2004) reported that a British company is developing a luciferase-based test to detect methicillin-resistant Staphylococcus aureus (MRSA) directly from patient samples.

According to your News story this new assay could be performed in a few hours, whereas other MRSA tests take days. This is not accurate. For example, a Swiss team has published a six-hour assay combining immunomagnetic enrichment of S. aureus cells with real-time polymerase chain reaction (PCR) amplification of speciesspecific and resistance genes (P. François et al. J. Clin. Microbiol. 41, 254-260; 2003).

More recently, our group developed a real-time PCR assay that was shown to be sensitive and specific for the detection of MRSA within one hour directly from nasal swabs (A. Huletsky et al. J. Clin. Microbiol. 42, 1875-1884; 2004). A commercial version of this test, manufactured by Infectio Diagnostic, has now been approved by the regulatory authorities of Canada and the United States and is available on the North American market for the diagnosis of MRSA carriers (www.infectio.com). It will soon be marketed in Europe.

The healthcare burden imposed by resistant bacteria is alarming. The use of clinically validated tests for the rapid diagnosis of MRSA is essential to improve management of antibiotic resistance in hospitals.

\section{Michel G. Bergeron, Ann Huletsky, François J. Picard, Maurice Boissinot Infectious Diseases Research Center, Université Laval, CHUQ (pavillon CHUL), 2705 boulevard Laurier, Quebec City RC-709, Quebec G1V 4G2, Canada \\ Fat chance of measuring food intake accurately}

Sir - The science of dieting, as Declan Butler observes in your News Feature "Slim pickings" (Nature 428, 252-254; 2004), is "painfully thin". Yes, but he is too kind. The problem is not merely a shortage of large, long-term, well-controlled trials. More fundamental is our inability to measure what people actually eat.

Most trials of free-living populations involve assigning subjects to alternative diets. Their food intake is measured, if at all, by one of the conventional instruments — food questionnaires, diaries, duplicate portions. All these methods share the same weakness: they depend on people honestly telling researchers what they consumed.

In most trials, there is no independent measure of food intake. 'Independent', in this context, means a biochemical or physiological indicator of the nutrients and other food components consumed. Yet it is universally recognized that most people underreport how much they eat. And overweight people underreport most of all, sometimes by more than $50 \%$. So we do not know to what degree, if at all, subjects were actually following the diets to which they were assigned.
Experiments in sealed metabolic wards have total control over food portions. But these are small, short-term studies in artificial conditions. Getting free-living volunteers to drink double-labelled water — containing markers which allow their urine to be measured for energy expenditure - is an acceptable surrogate measure, but too expensive to be used in the large, long-term trials that are needed.

In contrast, we have precise measures for the dependent variables, such as weight. But these days, serious trials also attempt to measure the effects of alternative diets on other important biochemical indicators, such as serum cholesterol or triglycerides.

With these measures, researchers sometimes draw conclusions that one diet is better for, say, the heart than the other. Yet they do not know if their subjects were actually eating different diets. They are trying to correlate two variables, without having adequately measured one of them.

Only when we can measure accurately both total energy intake and its component parts will we be able to determine which diets yield sustainable weight loss. These measures must be practical for use in trials on large numbers of free-living subjects over long periods. So they must be cheap, rapid, non-intrusive, painless, self-administrable, and capable of direct data transmission. This will require developments in technology as well as in basic science.

In sum, accurate measurement of food intake is the foundation stone for a true science of dieting.

\section{J. T. Winkler}

Food \& Health Research, 28 St Paul Street,

London N1 7AB, UK 